\title{
Influence of phytoplankton diet mixtures on microalgae consumption, larval development and settlement of the Pacific oyster Crassostrea gigas (Thunberg)
}

\author{
B. Rico-Villaa, J.R. Le Coza, C. Minganta and R. Robert*
}

\begin{abstract}
aUMR PE2M, Ifremer, Laboratoire de Physiologie des Invertébrés Marins, Station Expérimentale d'Argenton,
\end{abstract} Presqu'île du Vivier, 29840 Landunvez, France

*: Corresponding author : Tel.: +33 2988951 05; fax: +33 2988957 77. rrobert@ifremer.fr

\begin{abstract}
Microalgae commonly used as feed for bivalves, Pavlova lutheri $(P)$, Isochrysis affinis galbana $(T)$ and Chaetoceros calcitrans forma pumilum (Cp), were fed to Pacific oyster Crassostrea gigas to assess their nutritional value for larval development and metamorphosis during two experiments. Monospecific, bispecific and trispecific diets were firstly evaluated during 3 weeks from $D$ larvae to young postlarvae. Then bispecific diets, based on different $\mathrm{T}$ and $\mathrm{Cp}$ proportions, were assessed during a similar period. Concurrently, ingestion was studied through the whole larval and postlarval development for each diet and/or diet mixture. Because lipids are assumed to be a key nutrient for bivalves, biochemical analysis was undertaken on the second set of trials focused on fatty acids and sterols. Compared to the other diet mixtures (mono and plurispecific diet) TCp induced the best larval growth performance (13.2 $\mu \mathrm{m}$ day- 1), a high larval survival (98\%) but did not result in higher metamorphosis (72\%). In contrast, monospecific diet $\mathrm{P}$ was the poorest for larvae with low growth and low survival. When varying $\mathrm{T}$ and $\mathrm{Cp}$ proportions, best larval developments were induced with $25 \mathrm{~T} / 75 \mathrm{Cp}$ and $50 \mathrm{~T} / 50 \mathrm{Cp}$ diets, though quite similar to that obtained with $75 \mathrm{~T} / 25 \mathrm{Cp}$. In contrast, unbalanced diets $(95 \mathrm{~T} / 5 \mathrm{Cp}$ and $95 \mathrm{Cp} / 5 \mathrm{~T})$ led to low larval performances. In addition, grazing experiences showed preferential uptake of microalgae with $\mathrm{P}<\mathrm{PT}$ much less-than T much less-than $\mathrm{Cp}$ much less-than TCp = PCp = PTCp. For mixed diets a low daily consumption $(<10000$ microalgae per larvae) was noted during the first week followed by a second phase (next 8-10 days) with a sharp increase and regular intake, reaching 90000 microalgae per larvae per day. Finally, a marked drop (40 000 microalgae per larvae) was observed at the beginning of metamorphosis from days 20 to 21 . Principal component analysis between main fatty acids (19) and sterols (7) detected in larvae and postlarvae was used to discriminate profiles according to diets and/or metamorphosis competence. The correlation circle representation showed that the 26 variables are well explained by these combined variables (78\%) with a repartition along the first principal component according to diets with a gradient from $5 \mathrm{~T} / 95 \mathrm{Cp}$ to $95 \mathrm{~T} / 5 \mathrm{Cp}$. In contrast, postlarvae and larvae were discriminated on the second principal component while no relationships were found between competent and incompetent larvae.
\end{abstract}

Keywords: Crassostrea gigas; Larvae; Growth; Metamorphosis; Grazing; Lipids 


\section{Introduction}

French oyster farming is dominated by the cupped Crassostrea gigas with 107390 tons vs 1650 tons of the flat oyster Ostrea edulis (AGRESTE, 2005). This major production used to depend on natural spat collection but there is an increased reliance on hatchery spat in France from 5-10\% in 2000 to over $30 \%$ in 2003 (Scheffer et al., 2003). Now, despite an indisputable know-how in mollusc hatchery some biological aspects are still unknown and beyond them bivalve feeding requirements are poorly understood (Knauer and Southgate, 1999; Volkman and Brown, 2006). Bivalves, unlike larvae fish and crustaceans, are fed microalgae directly. Consequently, bivalve development is closely related to the quantity and quality of phytoplankton available. To be used as food for bivalve larvae, microalgae must exhibit some specific characteristics such as an adequate size for its ingestion (less than $10 \mu \mathrm{m}$ with an optimal range of 2 to $5 \mu \mathrm{m}$ ), no thick cell wall for its digestion, a good food value (adequate biochemical composition) and, for practical and economical reasons, must be relatively easy to be bulk produced (Robert and Trintignac, 1997). Because a mixed algal diet increases the chances of achieving a balanced diet, microalgae are generally supplied in plurispecific rations for bivalves without a clear knowledge of their need in essential components (Muller-Feuga et al., 2003a).

However, significant larval production in hatchery relies on this empirical feeding method. Indeed each experimental or commercial hatchery has its own microalgae mixture, which can change throughout larval development (Coutteau and Sorgeloos, 1992). Despite its diversity, a combination of at least a Haptophyceae and a Bacillariophyceae is often used (Robert and Gérard, 1999).

The empirical diet used for Crassostrea gigas larvae in the experimental hatchery of Argenton (North Brittany) was derived from that applied routinely for the scallop Pecten maximus (Robert et al., 1994). This mixture, named PTCp, consists of two prymnesiophytes, Pavlova lutheri (Droop) and Isochrysis affinis galbana (Green), clone t. Iso, together with the diatom Chaetoceros calcitrans forma pumilum (Takano). While the role of each microalga on larval development and metamorphosis was known for P. maximus (Delaunay et al., 1993) such basic information was unavailable for $C$. gigas in our larval rearing context and the literature did not report complete data throughout the whole larval stage. Moreover, larval development performances have been widely studied from a biochemical angle (see Brown et al., 1997; Knauer and Southgate, 1999). However, that sole approach is insufficient to define the appropriate diets for bivalves. Indeed, the literature shows the nutritional key roles of two essential fatty acids, eicosapentaenoic (20:5n-3, EPA) and docosahexaenoic (22:6n-3, DHA) acids. However, though $P$. lutheri is relatively well balanced in both fatty acids, it does not support good growth for $C$. gigas larvae (Ponis et al., 2003), despite a suitable size for early stages (Robert et al., 2004). On the other hand, few studies on microalgae ingestion by bivalve larvae have been reported and were essentially targeted on cell size (Walne, 1963; Bayne, 1965; Riisgard and Randlov, 1981; Sprung, 1984). However, Gerdes (1983) showed a consumption increase by larvae when using mixed vs a single diet. To our knowledge such information has never been confirmed and the objective of the present work was to study effective consumption by veligers exposed to different monospecific, bispecific and trispecific diets in relation to $C$. gigas larval development performance based on growth, survival and metamorphosis. Such quantitative and qualitative diet constituted a prerequisite for future work dealing with improvement of $C$. gigas larval and/or postlarval development such as research of new microalgae (Ponis et al., 2005) and/or physiological indices (Ben Kheder et al., 2005). 


\section{Materials and methods}

\subsection{Microalgae}

Five microalgae were used for broodstock conditioning and larval development. Many confusions in the identity of specific microalgae have been reported in the past and a target study was dedicated to clarify the situation. Growth, size, biochemistry profile, biomolecular and cytofluorimetry prints have been achieved for 15 microalgae used in Argenton hatchery as food for bivalves (Robert et al., 2004). Because such detailed information is now available, we only specify that microalgae used in the present study were originated from the Culture Collection of Algae and Protozoa (GB) such as Isochrysis affinis galbana (CCAP 927/14), Pavlova lutheri (CCAP 931/1), Chaetoceros calcitrans forma pumilum (CCAP 1010/05), Skeletonema costatum (CCAP1077/3), and that of the University of Texas (US) for C. gracilis (UTEX LB 2658). Microalgae used for larvae exhibited similar size in their exponential phase of growth (40 to 45 $\mu \mathrm{m}^{3}$ equivalent to 4.2 to $4.4 \mu \mathrm{m}$ diameter) as well as similar dry individual weight (18 to $20 \mathrm{pg}$ : Robert et al., 2004) and mixed feeding ration was accordingly based on a ratio 1/1.

\subsection{Broodstock conditioning and larval development}

Broodstock were conditioned at $19^{\circ} \mathrm{C}$, in a flow through system, with a daily mixed diet of $6 \% I$. aff. galbana, C. gracilis and S. costatum per mg oyster (dry algal weight/dry meat weight).

Six weeks later, gametes from 3 males and 6 females, obtained by scarification, were fertilized on the basis of 50 spermatozoa per oocyte and 2 hours later 40 embryos $\mathrm{ml}^{-1}$ were stocked in $150 \mathrm{l}$ culture tanks for further development. Two day old D larvae were then distributed in $30 \mathrm{l}$ cylindro-conical tanks at the density of 5 larvae $\mathrm{ml}^{-1}$, in $1 \mu \mathrm{m}$ filtered seawater at $25^{\circ} \mathrm{C}$ and $34 \%$ salinity. Aeration was maintained throughout the whole larval life at $0.5 \mathrm{l} \mathrm{min}^{-1}$ to avoid diatoms and debris deposition promoting bacterial source of infection. Seawater renewal and tank cleaning occurred three times a week with no antibiotic addition. Larvae were fed daily on different sole or mixed diets, however at equal quantity and adjusted to increasing larval demand (Table 1). At each draining, larvae were retained by a $40 \mu$ mylon mesh-based sieve during the first week and then on $60 \mu \mathrm{m}$. Few or no larvae were lost during mesh aperture change (necessary to avoid sieve clogging) and accordingly, larval performances reported in the present work relate to the whole population. Larval length and survival were estimated on days 2, 7 or 9, 14 or 16 and 19 by use of image analysis technique (WinImager 2.0 and Imaq Vision Builder 6.0 software for images capture and treatment, respectively).

\subsection{Metamorphosis}

In C. gigas metamorphosis occurs when larvae are $\geq 280 \mu \mathrm{m}$ (Coon et al., 1990; Utting and Spencer, 1991). The number of pediveligers ready to set (competent larvae: presence of an eyespot) was estimated prior to a selective grading on a $225 \mu \mathrm{m}$ aperture sieve mesh. Then, after counting, the largest larvae were transferred in $30 \mathrm{l}$ tanks in presence of $15 \mathrm{~cm}$ diameter plastic disks, used as collectors, representing a removable setting surface of $2400-3200 \mathrm{~cm}^{2}$. During metamorphosis rearing techniques were similar to those applied for earlier larval stages. Six to seven days later, experiments ended and settlement was evaluated by counting precisely the number of remaining pediveligers while an estimation of spat attached to collectors and tank walls were performed to check data validity. 
The influence of diets on larval performances was assessed using one-way ANOVA while significant differences $(P \leq 0.05)$ between treatments were compared using the Scheffé's pairwise multiple comparison test (Statview 5.0). Survival, yield, competency and metamorphosis data were previously transformed (arcsin [square (x/100)]) before analysis.

\subsection{Grazing}

For each nutritional condition, phytoplankton consumption was evaluated concurrently to establish potential correlation between larval development measures and algal cells ingestion. Microalgae used for larvae had similar cell size and were delivered, in different mixed diets, on an equal number of cells per $\mu \mathrm{l}$ of the culture tank volume. As larval development proceeds, biomass of larvae is ever increasing and food ration was adapted to support maximum larval growth. Such demand was previously established in $150 \mathrm{l}$ cultures using bispecific diet and such results were applied in the present work as a guide (theoretical demand: Table 1). PTCp and 50T/50Cp were the reference diets, detailed below, during experiments 1 and 2 respectively and when food limitation was detected in the controls, daily rations were adjusted accordingly and applied to the other nutritional conditions. Grazing was studied from D larvae to pediveligers including metamorphosis for all diets. Cell consumption was measured with an electronic particle counter ZM equipped with a $100 \mu \mathrm{m}$ aperture tube. Ten minutes after food delivery and homogenization, enriched seawater was sampled in triplicate in each tank through a $40 \mu \mathrm{m}$ mesh sieve, to measure initial cell concentration. An additional sample was taken the following day (18 to $20 \mathrm{~h}$ later) and food uptake evaluated. Because larval survival was checked regularly, a value for the mean grazing per larvae per unit of time was established for all diets.

\subsection{Experimental trials}

Two sets of trials were carried out in April and October 2004. During the first set of experiments, the influence of monospecific diets $(\mathrm{P}=P$. lutheri, $\mathrm{T}=\mathrm{t}$. Iso and $\mathrm{Cp}=C$. calcitrans $\mathrm{f}$. pumilum $)$, and bispecific diets (PT, PCp and TCp) on larval growth, survival and metamorphosis were studied. Positive controls consisted in trispecific diet PTCp while unfed larvae were the negative controls. Apart from starved larvae maintained in 51 beakers, larval rearing was operated in $30 \mathrm{l}$ tanks, in triplicate, across 8 treatments. The second set of experiments dealt with the effects of bispecific diets mixed in different proportions, on larval development and settlement. Unfed larvae were used as negative controls while five nutritional mixtures, 5T/95Cp, 25T/75Cp, 50T/50Cp, 75T/25Cp and 95T/5Cp were applied, in triplicate.

\subsection{Biochemical analysis}

The deficiency in fatty acids (EPA or DHA) of monospecific diets and its effects on C. gigas larval development are well documented (Waldock and Nascimento, 1979; Thompson and Harrisson, 1992; Thompson et al., 1996) and therefore such biochemical analysis was not undertaken in trial 1. In contrast, the effects of mixed diet based on different proportions of prymnesiophyte/bacillariophyte have not been reported in the literature to our knowledge. Because lipids are assumed to be key nutrient for bivalves, biochemical analysis performed on the second set of trials focused on fatty acids and sterols. $10^{5}$ eggs, $5 \times 10^{5} \mathrm{D}$ larvae, $10^{5}$ pediveligers and 2000 spat were sampled for each nutritional combination at days 0, 2, 19 and 26, respectively. Prior to metamorphosis, larvae were graded and analysis performed on the group of 
competent larvae (C) as well as the incompetent (NC) fraction (not retained on $225 \mu$ m nylon mesh). Concurrently 3 to 7 day old microalgae, used as feed for larvae during that experimental set, were collected twice a week, corresponding to seven different batches of culture per species. Biochemical analyses were performed on such biomass during the whole larval and early spat developments. Samples were collected on GF/C glass fibre filters and extracted in chloroformmethanol according to Folch et al. (1957). The neutral and polar lipids were separated in a silica gel microcolumn (30 mm x 5 mm; Kieselgel Merck, 70-230 $\mu$ m mesh), previously heated to $450^{\circ} \mathrm{C}$ and deactivated with 5\% water as described by Soudant et al. (1995), and analyzed following the method described by Marty et al. (1992). Collected fractions were used both for fatty acid (Marty et al., 1992) and sterol analyses (Soudant et al., 1998).

\section{Results}

\subsection{Larval development and metamorphosis}

TCp was the best diet leading to high survival, 98\% and growth, $13.2 \mu \mathrm{m} \mathrm{d}^{-1}$ (Table 2). Larvae fed exclusively C. calcitrans f. pumilum exhibited an acceptable growth, however with lower survival on day 16 (76\%) and characterized by a high intertank variability (CV=26\%). In contrast, feeding larvae with $P$. lutheri led to a poor development, low growth and low survival, similar to starved larvae performances (Table 2).

While the number of pediveligers competent to metamorphosis (greater than $280 \mu \mathrm{m}$ ) was highest on day 16 for TCp diet (70\%) metamorphosis, recorded one week later, was similar to the other mixed diets (72-77\%) - except PT -, that never led to competent larvae (Table 3). In contrast, larvae fed solely on C. calcitrans forma pumilum exhibited lower larval competence on day 16 (18\%, Table 3) and lower metamorphosis (54\%, Table 3) which was also characterized by an appreciable intertank variability $(\mathrm{CV}=19 \%)$ In contrast, the larvae fed the other diets did not show any competence on day 16 . Despite a prolonging of their rearing a similar situation occurred on day 22. The integration of the whole rearing performances was represented by the final yield (Table 3) corresponding to the number of postlarvae/initial number of D larvae (D22/D2). Similar overall rearing efficiencies, 25-30\%, were noted for PTCp and TCp diets while the use of $C$. calcitrans forma pumilum as feed throughout the whole larval process led to only $7 \%$ (Table 3).

When varying proportions from 5 to 95\% of each microalgae in bispecific diets TCp, high growth, $12.6 \mu \mathrm{m} \mathrm{d}^{-1}$, high survival, 99\% (Table 4), high larval competence and metamorphosis (78\% and $87.5 \%$ respectively, Table 5) were obtained with 50T/50Cp. Similar performances were reported with 25T/75Cp diet (Tables 4 and 5) while a $10 \mu \mathrm{m}$ difference in length was noted for 75T/25Cp diet from day 7 (Table 4) leading to lower competence on day 19, 53\%, with however a negligible effect on metamorphosis, 83\% (Table 5). Unbalanced diets, 95T/5Cp and 5T/95Cp produced lower larval growth from week 1 or 2, respectively (Table 4), lower survival, 60-75\% (Table 4) and lower larval competence, 17-28\% (Table 5). A high intra tank heterogeneity of larvae fed with an excess of $t$. Iso (95T/5Cp) was noted with two subpopulations, the first with a normal development and the second with poor growth. The situation was totally different when larvae were fed with a deficiency in t. Iso (5T/95Cp) where a high variability also occurred, but at an inter tank level. Because metamorphosis competence was lower than $50 \%$ on day 19 , no measure on settlement was performed for these unbalanced diets. In this second set of experiments, unfed larvae had similar performances to those recorded previously with negligible growth $0.4 \mu \mathrm{m} \mathrm{d}^{-1}$ and low survival, 30\% (Table 4). 


\subsection{Larval grazing}

For Experiment 1, grazing was determined for all diets, throughout larval development from days 6 to 15, and during metamorphosis up to day 22 for three of them (PCp, TCp and PTCp). Such a study, performed for each condition in triplicate and expressed as the number of cells eaten per day per larva, showed a preferential uptake of microalgae with $\mathrm{P}<\mathrm{PT}<<\mathrm{T}<<\mathrm{Cp}<<\mathrm{TCp}=\mathrm{PCp}=$ PTCp. When solely fed $P$. lutheri, a C. gigas larva only consumed 1000 to 3000 per day from days 6 to 15 (Fig. 1a). Associated with I. affinis galbana, uptake of such haptophytes mixture (PT) was weakly improved with a daily consumption of 1800 to 5000 for a similar period (Fig. 1b). With a grazing of 1000 to 15000 cells per larva per day, a better ingestion of t. Iso was paradoxically observed when larvae were fed on that single diet (Fig. 1c). Over a similar period, 7000 to 65000 cells of $C$. calcitrans forma pumilum were removed, however with high intertank variations (Fig. 1d). When this diatom was mixed with t. Iso or P. lutheri a higher consumption was recorded as well as excellent pattern reproductivity. Indeed from days 6 to 15, larvae fed bispecific diets grazed daily 8000 to 35000 microalgae to reach 85000 on day 21. Food uptake decreased during metamorphosis (Fig. 1e). The addition of another haptophyte (P) to these bispecific diets did not increase consumption (data not reported) and grazing patterns were remarkably similar as those reported in Fig. 1e.

A thorough study performed during the second set of experiments with bispecific diets containing different proportions of $\mathrm{T}$ and $\mathrm{Cp}$ (apart from the unbalanced diets 95T/5Cp and 5T/95Cp) led to the identification of three phases. The first phase was characterised by a low consumption during the first ten days with a daily removal of 10000 to 20000 microalgae per larva (Fig. 2). Then, up to day 20, an increased food uptake was recorded with values as high as 90000 cells $\mathrm{d}^{-1}$ followed by a sharp 50\% decrease in consumption during metamorphosis. Grazing recovered progressively until day 24 (60 000 microalgae per larva, Fig. 2).

\subsection{Biochemical analysis}

Fatty acid (FA) and sterol composition of both microalgae I. affinis galbana and C. calcitrans forma pumilum, of 19 day-old larvae and new settled postlarvae ( $\leq 5 \mathrm{~d}$ old) were determined. The diatom C. calcitrans forma pumilum was rich in 16:1n-7, 20:5n-3, cholesterol, 24-

methylencholesterol and isofucosterol while t. Iso contained 14:0, 18:2n-6, 18:4n-3, 22:6n-3 and brassicasterol (Table 6).

The biochemical composition of 19d old larvae and 5d old postlarvae was clearly related to diet composition. For instance, brassicasterol, derived from t-Iso, was found at 55\% in the larvae fed 95T/5Cp but only at 3.4\% in the larvae fed 5T/95Cp (Table 6). Similarly 20:5(n-3) and 24methylencholesterol reflected the relative quantity of $C$. calcitrans forma pumilum eaten by larvae (Table 6).

Principal component analysis between main fatty acids (19) and sterols (7) detected in larvae and postlarvae was used to discriminate profiles according to diets and/or metamorphosis competence. Four components with eigenvalues higher than 1.0 explained $92 \%$ of the variability in the original data. The first principal component (PC1) explained $54.2 \%$ of the combined variance while 23.3\% was explained by the second component (PC2). A correlation circle was plotted using PC1 and PC2 (Fig. 3). This representation showed that the 26 variables are well explained by these combined variables (78\%) with a repartition along PC1 according to diets with a 
gradient from 5T/95Cp to 95T/5Cp. In contrast, postlarvae and larvae were discriminated on PC2 while no relations were found between competent and incompetent larvae (Fig. 3).

\section{Discussion}

Production of bivalves in hatcheries is undoubtedly related to the quality and the quantity of the supplied microalgae (Helm and Bourne, 2004). Moreover, with the present techniques used, the phytoplankton production can represent 30 to $40 \%$ of the spat cost in hatcheries (Helm, 1990; Coutteau and Sorgeloos, 1992; Borowitzka, 1999). The choice of the cultivated microalgae to be used as feed is accordingly an important one.

The influence of microalgae biochemical composition on larval and juvenile development has been widely reported in bivalves (Webb and Chu, 1983; Brown et al., 1997; Robert and Trintignac, 1997; Knauer and Southgate, 1999; Muller-Feuga et al., 2003a, b; Volkman and Brown, 2006) and it is now well known that 20:5n-3 and 22:6n-3 are both essential fatty acids for oysters as previously shown by Langdon and Waldock (1981). Nevertheless, the exclusive use of Thallasiosira pseudonana (Thomson and Harrison, 1992) or Chaetoceros gracilis (Thompson et al., 1993) both rich in 20:5n-3, led to inconsistent results without ensuring better performances in Crassostrea gigas larval growth. Similarly, in the present study, the use of the sole diet Chaetoceros calcitrans forma pumilum (Cp), rich in the same fatty acid resulted in a high interspecific larval survival variability. In contrast, moderate levels of 20:5n-3 (EPA) and 22:6n-3 (DHA) led to good rearing performances because when a mixed diet (TCp) was used (from 25 to $75 \%$ of each of its component) little or no difference in larval growth occurred. Assuming that on day 19 competent larvae reflected the end of the larval cycle as well as the cumulative effect of each diet throughout the whole larval life, we can estimate that good larval developments were obtained when larvae contained $7 \%<\mathrm{EPA}<17 \%$ and $7 \%<\mathrm{DHA}<14 \%$ (Table 6 ). Such results are consistent with those of Thompson and Harrison (1992) who reported that good larval performances were associated to an EPA content in diets of 6 to 18\%. On the other hand, EPA and DHA within each corresponding diet were similar between competent and incompetent larva, this criteria being based on adequate size and the presence of eyespot. This means that, in our conditions, all the larvae had the ability to go through metamorphosis when anatomical criteria would be attained and that it was just of question of time. Or, these specific biochemical components are not the only appropriate keys for explaining metamorphosis.

On the other hand, several fatty acids, mainly 20:1n-7, 22:2i and 22:2j, were present in the oyster (larvae and spat) while undetected in microalgae. Ackman and Hooper (1973) explained that 20:1n-7 could come from an elongation process of 16:1n-7. This fatty acid was particularly abundant here in Cp. Besides, 22:2i and 22:2j have been identified as non-methylene interrupted (NMID) 22 carbon fatty acids whose physiological significance are unknown. Because these fatty acids were present in the starved larvae several days later a structural role rather than a storage function has been considered by some authors (Thompson and Harrison, 1992). Nevertheless, the nutritional value of microalgae for bivalve larvae depends, above all else, on the cell size and/or the presence of short spines allowing its accessibility and ingestion (Robert and Trintignac, 1997) while the nature and thickness of the cell wall will explain its digestibility, some species being ingested but poorly digested (Babinchak and Ukeles, 1979; Robert, 1998). The three microalgae used in the present study are known to have similar sizes and fine cell walls (Chrétiennot-Dinet et al., 1986) but, despite their similarity, a preferential consumption was shown according to the microalgal species and type of diet. In the first set of feeding trials which evaluated monospecific diets, a preference was found for $C$. calcitrans forma pumilum with an 
uptake of 10000 to 66000 cells d $^{-1}$ larva $^{-1}$ at the beginning of rearing (first 12 days) then with $I$. aff. galbana whose consumption did not exceed 15000 cells during the same period. P. lutheri was also ingested at a very low level, approximately ten times less than I. aff. galbana. Larvae fed bispecific PT showed a weak and constant grazing behaviour throughout the whole rearing period, somewhat higher than that noted with the sole $P$. lutheri but lower than recorded with $I$. aff. galbana. Moreover, a clear preference towards the assemblages composed of flagellates (P or T) and Cp was observed. Indeed, PCp and TCp uptakes were high, similar to that recorded on trispecific diet PTCp. This means that, with the microalgae used here, there was no advantage in term of consumption to supply an association of three algae compared to two.

During the second set of experiments, the diet containing the greatest amount of diatom (5T/95Cp) exhibited an equivalent consumption to that detected on the sole $C$. calcitrans forma pumilum during the first set of experiments. Similar behaviour occurred with the richest haptophyte diet 95T/5Cp compared to T alone. Lastly, for the well balanced diet 50T/50Cp in experiment 2, similar uptake as TCp in experiment 1 was reported showing a good reproducibility between experiments despite different breeding seasons, i.e. spring and fall. Diets composed exclusively with Cp or with this alga present in high proportion in the assemblage, 5T/95Cp, showed large interspecific differences that might be explained by some harmfulness for larvae. A similar phenomenon has been already reported on copepods (Ianora et al., 2003) where diatoms exhibited teratogenic effects in certain conditions. Many complex lipids are readily hydrolysed to yield free fatty acids and several studies have suggested that specific free acids can be toxic (Volkman and Brown, 2006). The formation of free fatty acids due to autolysis on cell rupture seems to be a particular problem with Skeletonema costatum (Berge et al., 1995) and whether C. calcitrans forma pumilum has similar properties needs to be validated. On the other hand, in the assemblages (except PT weakly ingested) the species selectivity disappeared, at least in our scale sampling, generally 24 hours and the patterns of the consumption for larvae fed PCp and TCp were similar.

A good intertank reproductibility in the grazing results allowed us to clearly identify three periods. The first starting from D larvae (D2 $\geq 70 \mu \mathrm{m})$ to early hinged larvae (D8 $\geq 120 \mu \mathrm{m})$ was characterized by a low but progressive phytoplankton consumption with values from 600 to 4000 cells $\mathrm{d}^{-1}$ larva $^{-1}$. This period represents the beginning of the larval life where larval metabolism is partially sustained by reserves. The second phase related to hinged to eyed competent larvae. During this period grazing increases considerably passing from 6000 to 25000 cells d $^{-1}$ larva $^{-1}$ between $10^{\text {th }}$ and $15^{\text {th }}$ day with 80000 to 90000 cells $\mathrm{d}^{-1}$ larva ${ }^{-1}$ the $21^{\text {st }}$ day, while larvae grew actively $\approx 15 \mu \mathrm{m} \mathrm{d}^{-1}$ vs $8 \mu \mathrm{m} \mathrm{d}^{-1}$. This period was very well marked during the two experimental series, though somewhat less pronounced for 75T/25Cp. Similar consumption has been already reported by Utting and Spencer (1991) on C. gigas larvae from 120 to $300 \mu \mathrm{m}$ fed on Isochrysis affinis galbana. A third period was noted for larvae $\geq 320 \mu \mathrm{m}$ during which ingestion decreased suddenly. This size is known to be critical for oyster larvae because they are normally competent to metamorphosis and ready to settle (Gerdes, 1983; Helm and Bourne, 2004). Indeed during metamorphosis the velum degenerates while the gills are not yet functional (Cannuel and Beninger, 2006) and accordingly filtration capacity is reduced (Baker and Mann, 1994). Finally, a fourth period during the second set of experiments was detected from the $21^{\text {st }}$ day corresponding to the resumption of feeding uptake, however remaining slightly lower than that preceding metamorphosis. This resumption occured 24 hours later which is in agreement with the results of Baker and Mann (1994) who reported that, except for only a few hours during the settler phase, feeding was possible throughout $C$. virginica metamorphosis. These marked 
differences during evolution of phytoplankton consumption clearly reflected larval development. The qualitative influence of the different diet is conspicuous at the end of the first week of rearing but strengthened beyond. Larvae fed solely $P$. lutheri showed a weak ingestion, leading to low growth $\left(1.7 \mu \mathrm{m} \mathrm{d}^{-1}\right)$ and survival (29\%) at the end of the experiment confirming previous work on the same species (Ponis et al., 2003). In contrast, $P$. lutheri has been successfully used with scallop larvae such as Pecten maximus (Delaunay et al., 1993), Pecten fumatus (Heasman et al., 1995), Mimachlamys asperrima (O’Connor and Heasman, 1997). A moderate growth ( $\approx 6.0$ $\mu \mathrm{m} \mathrm{d}^{-1}$ ) characterized $C$. gigas larval development solely fed t. Iso. Moreover, survival remained high at the end of three weeks of rearing (86\%) and confirmed previous data on the same species (Helm and Laing, 1987). Compared to performances recorded with I. aff. galbana, addition of $P$. lutheri improved slightly larval growth $\left(7.4 \mu \mathrm{m} \mathrm{d}^{-1}\right)$ but not survival (82\%). Isochrysis aff. galbana utilization is accordingly preferential for $C$. gigas larvae. However, $P$. lutheri might be maintained in the hatchery as an alternative of I. aff. galbana in case of culture collapse. In contrast, C. calcitrans forma pumilum led to good growth $\left(10 \mu \mathrm{m} \mathrm{d}^{-1}\right)$ and it is thus an essential constituent for $C$. gigas larval growth, although insufficient as a sole diet. Indeed, its sole use led to a high survival variability, low larval competence and metamorphosis.

Both bispecific diets TCp and PCp led to similar growth, survival and competence. However, T exhibited higher food value than $\mathrm{P}$ when used as single diet, and TCp was accordingly preferred. Between different mixtures, 50T/50Cp appeared to be the best for larval development and metamorphosis while unbalanced rations (5T/95Cp or 95T/5Cp) are not advised due to a negative effect on growth and survival.

Excellent reproductibility of larval development performances between both sets of experiments has to be noted. Growth of larvae solely fed t. Iso (exp. 1) or mixtures rich in this haptophyte (95T/5Cp: exp. 2) were very similar (6vs $\left.8 \mu \mathrm{m} \mathrm{d}^{-1}\right)$ while similar growth $\left(10 \mu \mathrm{m} \mathrm{d}^{-1}\right)$ were recorded when larvae were fed $C$. calcitrans forma pumilum (exp. 1) and mixtures rich in this diatom (5T/95Cp: exp. 2), or with the diet TCp (exp. 1) and 50T/50Cp (exp. 2) with a daily growth of $13 \mu \mathrm{m} \mathrm{d}^{-1}$. Moreover, in both sets of experiments starved larvae growth was nil or insignificant confirming the absence of other exogenous feed components which gives confidence to the results reported here.

\section{Conclusion}

This study clearly shows than a bispecific diet based on the Haptophyte Isochrysis aff. galbana (T) and the diatom Chaetoceros calcitrans forma pumilum (Cp) in a proportion of one to one fits well to Crassostrea gigas larval demand and allows good development from 2 days old D larvae to one week old postlarvae. The addition of Pavlova lutheri (P) to TCp did not support any advantages in term of larval performance and metamorphosis, while the role of the diatom $C$. calcitrans $f$. pumilum in Crassostrea gigas growth is essential, contributing $75 \%$ of larval growth. Moreover C. gigas larval performances are clearly related to feeding behaviour, with a low ingestion of $P$. lutheri, a high ingestion of $C$. calcitrans forma pumilum, and a moderate ingestion of t. Iso. In presence of bispecific diets (except PT with almost a nil uptake), grazing largely increased with a high reproductivity of the pattern in all tanks.

\section{Acknowledgements}

The authors wish to acknowledge the support for the first author, Benjamin Rico-Villa, to Consejo Nacional de Ciencia y Tecnología (CONACyT, Mexico) through a scholarship and to Dr M. Brown for improving English. 


\section{References}

Ackman, R.G., Hooper, S.N., 1973. Non-methylene-interrupted fatty acids in lipids of shallowwater marine invertebrates: a comparison of two mollusks (Littorina littorina, and Lunatia triseriata) with the sand shrimp (Crangon septemspinosus). Comp. Biochem. Physiol. 46B, 153-155.

AGRESTE, 2005. Recensement de la conchyliculture 2001, Agreste Cahiers nº 1, février 2005, $89 \mathrm{pp}$.

Babinchak, J.A., Ukeless, R., 1979. Epifluorescence microscopy, a technique for the study of feeding in Crassostrea virginica veliger larvae. Mar. Biol. 51, 69-76.

Baker, S.M., Mann, R., 1994. Feeding ability during settlement and metamorphosis in the oyster Crassostrea virginica (Gmelin, 1791) and the effects of hypoxia on post-settlement ingestion rates. J. Exp. Mar. Biol. Ecol. 181, 239-253.

Bayne, B.L., 1965. Growth and the delay of metamorphosis of the larvae of Mytilus edulis (L.). Ophelia 2, 1-47.

Ben Kheder, R., Quéré, C., Mingant, C., Bejaoui, N., Le Pennec, M., Robert, R., 2005. Evolution of condition indices during Crassostrea gigas larval development. Larvi 05, Ghent, 5-8 September 2005, Belgium. Fish and Shellfish Larviculture Symposium, Hendry, C.I., Van Stappen, G., Wille, M., Sorgeloos, P. (Eds.), European Aquaculture Society, Special Publication No. 36, Oostende, Belgium, Book of Abstract pp. 26-29.

Berge, J.P., Gouygou, J.P., Dubacq, J.P., Durand, P., 1995. Reassessment of lipid composition of the diatom Skeletonema costatum. Phytochemistry 39, 1017-1021.

Borowitzka, M.A., 1999. Production of microalgal concentrates for Aquaculture (Part 1: Algae Culture). Final Report to the Fisheries Research and Development Corporation (Australia). Project 93/123. Fisheries Research and Development Corporation (Australia), Canberra, Australia, 70 pp.

Brown, M.R., Jeffrey, S.W., Volkman, J.K., Dunstan, G.A., 1997. Nutritional properties of microalgae for mariculture. Aquaculture 151, 315-331.

Cannuel, R., Beninger P.G., 2006. Gill development, functional and evolutionary implications in the Pacific oyster Crassostrea gigas (Bivalvia: Ostreidae). Mar. Biol., in press

Chrétiennot-Dinet, M.J., Robert, R., His, E., 1986. Utilisation des algues fourrage en aquaculture. Ann. Biol. 25(2), 97-116.

Coon, S.L., Fitt, W.K., Bonar, D.B., 1990. Competence and delay of metamorphosis in the pacific oyster Crassostrea gigas. Mar. Biol. 106, 379-387.

Coutteau, P., Sorgeloos, P., 1992. The uses of algal substitutes and the requirements for live algae in hatchery and nursery rearing of bivalve molluscs: An international survey. J. Shellfish Res. 11, 467-476.

Delaunay, F., Marty, Y., Moal, J., Samain, J.F., 1993. The effect of monospecific algal diets on growth and fatty acid composition of Pecten maximus (L.) larvae. J. Exp. Mar. Biol. Ecol. 173, 163-179.

Folch, J., Lees, M., Sloane-Stanley, G.H., 1957. A simple method for the isolation and purification of total lipids from animal tissues. J. Biol. Chem. 266, 497-509.

Gerdes, D., 1983. The pacific oyster Crassostrea gigas. Part I. Feeding behaviour of larvae and adults. Aquaculture 31, 195-219.

Heasman, M.P., O’Connor, W.A., Frazer, A.W., 1995. Evaluation of Hatchery Production of 
Scallops Pecten fumatus, Final Report to FRDC. NSW Fisheries, Taylor Beach, NSW, pp. 176.

Helm, M.M., 1990. Coltivazione di microalghe (Culture of microalgae). In: Allesandra, G. (Ed.). Tapes philippinarum. Biologia experimentazione, Ente Svillupo Agricolo Veneto, Venice, Italy, pp. 91-113.

Helm, M.M., Bourne, N., 2004. Hatchery culture of bivalves. A practical manual. FAO Fisheries Technical Paper 471, Rome, Italy, 177 pp.

Helm, M.M., Laing, I., 1987. Preliminary observations on the nutritional value of "Tahiti Isochrysis" to bivalve larvae. Aquaculture 62, 281-288.

Ianora, A., Poulet, A., Miralto, A., 2003. The effects of diatoms on copepod reproduction: a review. Phycologia 41, 351-363.

Knauer, J., Southgate, P.C., 1999. A review of the nutritional requirements of bivalves and the development of alternative and artificial diets for bivalve aquaculture. Rev. Fish. Sci. 7, 241-280.

Langdon, C.J., Waldock, M.J., 1981. The effect of algal and artificial diets on the growth and fatty acid composition of Crassostrea gigas. J. Mar. Biol. Assoc. U.K. 61, 431-448.

Marty, Y., Delaunay, F., Moal, J., Samain, J.F., 1992. Changes in the fatty acid composition of Pecten maximus (L.) during larval development. J. Exp. Mar. Biol. Ecol. 163, 221-234.

Muller-Feuga, A., Robert, R., Cahu, C., Robin, J., Divanach, P., 2003a. Uses of microalgae in aquaculture. In: StrØttrup, J.G., McEvoy, L.A. (Eds.), Live Feeds in Marine Aquaculture. Blackwell Publishing, Oxford, UK, pp. 253-299.

Muller-Feuga, A., Moal, J., Kaas, R., 2003b. The microalgae of aquaculture. In: StrØttrup, J.G., McEvoy, L.A. (Eds.), Live Feeds in Marine Aquaculture. Blackwell Publishing, Oxford, UK, pp. 206-251.

O’Connor, W.A., Heasman, M.P., 1997. Diet and feeding regimens for larval doughboy scallops Mimacchlamys asperrima. Aquaculture 158, 289-303.

Ponis, E., Robert, R., Parisi, G., Tredici, M., 2003. Assessment of the performance of Pacific oyster (Crassostrea gigas) larvae fed with fresh and preserved Pavlova lutheri concentrates. Aquacult. Int. 11, 69-79.

Ponis, E., Probert, I., Véron, B., Mathieu, M., Robert, R., 2005. New microalgae for the Pacific oyster Crassostrea gigas larvae. Larvi 05, Ghent, 5-8 September 2005, Belgium. Fish and Shellfish Larviculture Symposium, Hendry, C.I., Van Stappen, G., Wille, M., Sorgeloos, P. (Eds.), European Aquaculture Society, Special Publication No. 36, Oostende, Belgium, Book of Abstract pp. 408-411.

Riisgard, H.U., Randlov, A., 1981. Energy budgets, growth and filtration rates in Mytilus edulis at different algal concentrations. Mar. Biol. 61, 227-234.

Robert, R., 1998. Nutritional inadequacy of Nannochloris atomus and Stichoccocus bacillaris for the oyster Crassostrea gigas (Thunberg) larvae. Haliotis 27, 29-34.

Robert, R., Gérard, A., 1999. Bivalve hatchery techniques: current situation for the oyster Crassostrea gigas and the scallop Pecten maximus. Aquat. Living Resour. 12, 121-130.

Robert, R., Trintignac, P., 1997. Microalgues et nutrition larvaire en écloserie de molluques. Haliotis 26, 1-13.

Robert, R., Miner, P., Mazuret, M., Connan, J.P., 1994. L’écloserie expérimentale de mollusques d'Argenton, bilan et perspective. Équinoxe 49, 20-33.

Robert, R., Chrétiennot-Dinet, M.J., Kaas, R., Martin-Jézéquel, V., Moal, J., Le Coz, J.R., Nicolas, J.L., Bernard, E., Connan, J.P., Le Dean, L., Gourrierec, G., Leroy, B., Quéré, C., 
2004. Amélioration des productions phytoplanctoniques en écloserie de mollusques : caractérisation des microalgues fourrage, RI DRV/RA-2004-05, 149 pp.

Scheffer, H., Gaubert, Y., Francoual, M., Le Meur, J., 2003. Spécial naissain, l’Ostréiculteur Français 164, 20-25.

Soudant, P., Marty, Y., Moal, J., Samain, J.F., 1995. Separation of major lipids in Pecten maximus by high-performance liquid chromatography and subsequent determination of their fatty acids using gas chromatography. J. Chromat. 63B, 15-26.

Soudant, P., Le Coz, J.R., Marty, Y., Moal, J., Robert, R., 1998. Incorporation of microalgae sterols by scallop Pecten maximus (L) larvae. Comp. Biochem. Physiol. 119A, 451-457.

Sprung, M., 1984. Physiological energetic of mussel larvae (Mytilus edulis). I. Shell growth and biomass. Mar. Ecol. Prog. Ser. 17, 283-293.

Thompson, P.A., Harrison, P.J., 1992. Effects of monospecific algal diets of varying biochemical composition on the growth and survival of the Pacific oyster (Crassostrea gigas) larvae. Mar. Biol. 113, 645-654.

Thompson, P.A., Guo, M., Harrison, P.J., 1993. The influence of irradiance on the biochemical composition of three phytoplankton species and their nutritional value for larvae of the Pacific oyster (Crassostrea gigas). Mar. Biol. 117, 259-268.

Thompson, P.A., Guo, M., Harrison, P.J., 1996. Nutritional value of diets that vary in fatty acid composition for larval Pacific oyster (Crassostrea gigas). Aquaculture 143, 379-391.

Utting, S.D., Spencer, B.E., 1991. The hatchery culture of bivalve mollusc larvae and juveniles. Leaflet Laboratory of Ministry of Agriculture, Fisheries and Food, Directorate of Fisheries Research, Lowestoft, 68, 31 pp.

Volkman, J.K., Brown, M.R., 2006. Nutrional Value of Microalgae and Applications. In: Subba Rao, D.V. (Ed.), Algal Cultures, Analogues of Bloom and Applications, Science Publishers, Enfield (NH), USA; Plymouth UK, pp 407-457.

Waldock, M.J., Nascimento, I.A., 1979. The triacylglycerol composition of Crassostrea gigas larvae fed on different algal diets. Mar. Biol. Letters 1, 77-86.

Walne, P. R., 1963. Observations of food values of 7 species of algae to larvae of Ostrea edulis. 1. Feeding Experiments. J. Mar. Biol. Assoc. UK 43, 767-784.

Webb, K.L., Chu, F.E.L., 1983. Phytoplankton as a source of food for bivalve larvae. In: Pruder, G.D., Langdon, C., Conklin, D. (Eds.). Proceedings of the $2{ }^{\text {nd }}$ International Conference on Aquaculture Nutrition: Biochemical and Physiological Approaches to Shellfish Nutrition, October 1981, Rehoboth Beach, Delaware. Louisiana State University Press, Baton Rouge: 272-291. 


\section{Table 1}

Evolution of daily food ration (total number of algal cells per microliter) related with larval and/or postlarval age during both experiments from day 2 to 21 (from fertilization). During the second set of trials, metamorphosis extended until day 26 with a daily mean ration maintained at

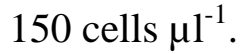

\begin{tabular}{|c|c|c|c|c|c|c|c|c|c|c|c|c|c|c|c|c|c|c|c|c|}
\hline $\begin{array}{c}\text { Age of larvae } \\
\text { (days) }\end{array}$ & 2 & 3 & 4 & 5 & 6 & 7 & 8 & 9 & 10 & 11 & 12 & 13 & 14 & 15 & 16 & 17 & 18 & 19 & 20 & 21 \\
\hline "Experiment 1 & 25 & 25 & 25 & 45 & 445 & 445 & 60 & 60 & 60 & 260 & 60 & 100 & 100 & 100 & 120 & 120 & 120 & 120 & 120 & 12120 \\
\hline Experiment 2 & 25 & 25 & 25 & 30 & 50 & 50 & 50 & 80 & 80 & 80 & 120 & 120 & 120 & 120 & 150 & 150 & 150 & 150 & 150 & 150 \\
\hline
\end{tabular}




\section{Table 2}

Mean shell length (SD) and survival (SD) of Crassostrea gigas larvae fed on different mono- or pluri-specific diets, with $\mathrm{P}=$ Pavlova lutheri, $\mathrm{T}=$ Isochrysis affinis galbana (clone t. Iso) and $\mathrm{Cp}$ = Chaetoceros calcitrans forma pumilum, on days 9 and 16. Values with same letters are not significant at $P>0.05$. Initial larval shell length on $\mathrm{D} 2=78.37 \mu \mathrm{m}(4.05)$.

\begin{tabular}{|c|c|c|c|c|}
\hline 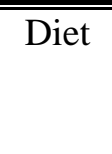 & $\begin{array}{c}\text { Length }(\mu \mathrm{m}) \\
\text { (D9) }\end{array}$ & $\begin{array}{c}\text { Survival (\%) } \\
\text { (D9) }\end{array}$ & $\begin{array}{c}\text { Length }(\mu \mathrm{m}) \\
\text { (D16) }\end{array}$ & $\begin{array}{c}\text { Survival (\%) } \\
\text { (D16) }\end{array}$ \\
\hline TCp & $166.13(23.99)^{c}$ & $99.83(0.12)^{a}$ & $263.51(49.56)^{\mathrm{g}}$ & $98.33(1.32)^{a}$ \\
\hline РCp & $148.60(20.88)^{a}$ & $99.47(0.35)^{\mathrm{a}}$ & $244.71(44.78)^{a}$ & $98.84(0.13)^{\mathrm{a}}$ \\
\hline РTCp & $154.53(20.35)^{a}$ & $99.29(0.42)^{\mathrm{a}}$ & $239.91(52.77)^{a}$ & $95.40(2.09)^{d}$ \\
\hline Cp & $149.30(17.68)^{a}$ & $99.80(0.15)^{\mathrm{a}}$ & $219.00(33.43)^{\mathbf{b}}$ & $76.19(20.16)^{b}$ \\
\hline PT & $126.49(23.21)^{d}$ & $99.88(0.15)^{\mathrm{a}}$ & $181.52(53.10)^{c}$ & $81.81(7.70)^{b}$ \\
\hline $\mathrm{T}$ & $110.19(17.04)^{e}$ & $99.22(0.58)^{a}$ & $162.98(41.40)^{d}$ & $85.98(7.88)^{b}$ \\
\hline $\mathrm{P}$ & $94.68(13.56)^{\mathbf{b}}$ & $99.67(0.41)^{\mathrm{a}}$ & $101.88(18.57)^{e}$ & $29.23(7.02)^{\mathrm{c}}$ \\
\hline Unfed & $89.44(6.62)^{b}$ & $99.15(0.25)^{\mathrm{a}}$ & $81.86(7.53)^{f}$ & $33.67(3.78)^{c}$ \\
\hline
\end{tabular}




\section{Table 3}

Mean number (SD) of pediveligers ready to set at the end of rearing period (D16), mean metamorphosis (SD) six days later (D22) and final harvest yield of Crassostrea gigas fed on different mono- or pluri-specific diets with $\mathrm{P}=$ Pavlova lutheri, $\mathrm{T}=$ Isochrysis affinis galbana (clone t. Iso) and $\mathrm{Cp}=$ Chaetoceros calcitrans forma pumilum. Values with same letters are not significant at $P>0.05$.

Diet $\quad$ Morphological competence (\%) $\quad$ Metamorphosis (\%)

Final yield (\%)

(D16)

(D22/D16)

(D22/D2)

\begin{tabular}{rrrr}
\hline \hline PTCp & $58.50(13.43)^{\mathbf{a}}$ & $77.36(1.58)^{\mathbf{a}}$ & $29.30(9.30)^{\mathbf{a}}$ \\
PCp & $47.66(8.50)^{\mathbf{b}}$ & $76.49(1.10)^{\mathbf{a}}$ & $16.60(4.60)^{\mathbf{b}}$ \\
TCp & $69.00(12.12)^{\mathbf{c}}$ & $72.02(0.89)^{\mathbf{a}}$ & $25.30(8.60)^{\mathbf{a}}$ \\
Cp & $18.36(11.53)^{\mathbf{d}}$ & $54.13(10.05)^{\mathbf{b}}$ & $7.18(6.59)^{\mathbf{c}}$ \\
\hline \hline
\end{tabular}




\section{Table 4}

Mean shell length (SD) and survival (SD) of Crassostrea gigas larvae fed on different proportions of Isochrysis affinis galbana (T) and Chaetoceros calcitrans forma pumilum (Cp) in bispecific diets TCp on days 7,14 and 19. Values with same letters are not significant at $P>0.05$. Initial larval shell length on D2=78.60 $\mu \mathrm{m}$ (6.02).

\begin{tabular}{|c|c|c|c|c|c|c|}
\hline Diet & $\begin{array}{c}\text { Length }(\mu \mathrm{m}) \\
\text { (D7) }\end{array}$ & $\begin{array}{l}\text { Survival (\%) } \\
\text { (D7) }\end{array}$ & $\begin{array}{c}\text { Length }(\mu \mathrm{m}) \\
\text { (D14) }\end{array}$ & $\begin{array}{c}\text { Survival (\%) } \\
\text { (D14) }\end{array}$ & $\begin{array}{c}\text { Length }(\mu \mathrm{m}) \\
\text { (D19) }\end{array}$ & $\begin{array}{c}\text { Survival (\%) } \\
\text { (D19) }\end{array}$ \\
\hline 5T - 95Cp & $107.01(13.38)^{a}$ & $99.71(0.26)^{a}$ & $162.90(24.26)^{\mathrm{e}}$ & $69.00(18.24)^{a}$ & $250.11(46.38){ }^{e}$ & $61.33(23.13)^{a}$ \\
\hline $25 \mathrm{~T}-75 \mathrm{Cp}$ & $114.71(13.98)^{b}$ & $99.75(0.15)^{\mathrm{a}}$ & $217.97(36.10)^{a}$ & $98.48(1.01)^{\mathbf{b}}$ & $290.46(36.60)^{a}$ & $98.45(0.53)^{\mathbf{b}}$ \\
\hline $50 T-50 C p$ & $115.30(13.84)^{b}$ & $99.70(0.28)^{\mathrm{a}}$ & $222.01(32.71)^{a}$ & $99.04(0.07)^{\mathbf{b}}$ & $293.45(38.28)^{a}$ & $98.87(0.84)^{\mathbf{b}}$ \\
\hline $75 T-25 C p$ & $106.82(15.18)^{a}$ & $99.58(0.33)^{a}$ & $210.18(39.60)^{b}$ & $97.89(0.60)^{\mathbf{b}}$ & $280.57(48.13)^{b}$ & $97.53(2.15)^{\mathbf{b}}$ \\
\hline $95 T-5 C p$ & $90.73(9.67)^{c}$ & $88.93(8.30)^{\mathbf{b}}$ & $137.31(47.70)^{c}$ & $76.57(3.95)^{\mathrm{a}}$ & $217.32(68.43)^{c}$ & $75.24(7.45)^{\mathrm{a}}$ \\
\hline Unfed & $86.08(6.24)^{d}$ & $99.35(0.18)^{\mathbf{a}}$ & $85.56(6.21)^{d}$ & $89.45(4.56)^{c}$ & $85.76(7.03)^{d}$ & $29.21(16.34)^{c}$ \\
\hline
\end{tabular}




\section{Table 5}

Mean number of pediveligers ready to set (SD) at the end of rearing period (D19), metamorphosis (SD) and final yield (SD) seven days later (D26) of Crassostrea gigas fed on different proportions of Isochrysis affinis galbana $(\mathrm{T})$ and Chaetoceros calcitrans forma pumilum (Cp) in bispecific diets TCp. Values with same letters are not significant at $P>0.05$. * No data.
Diet
Morphological competence (\%)
Metamorphosis (\%)
Final yield (\%)

(D19)

(D26/D19)

(D26/D2)

\begin{tabular}{cccc}
\hline \hline $5 T-95 C p$ & $17.51(13.46)^{\mathbf{b}}$ & $*$ & $*$ \\
$25 \mathrm{~T}-75 \mathrm{Cp}$ & $75.93(3.64)^{\mathbf{a}}$ & $85.88(9.60)^{\mathbf{a}}$ & $54.30(8.30)^{\mathbf{a}}$ \\
$50 \mathrm{~T}-50 \mathrm{Cp}$ & $78.15(5.15)^{\mathbf{a}}$ & $87.45(7.11)^{\mathbf{a}}$ & $54.60(9.60)^{\mathbf{a}}$ \\
$75 \mathrm{~T}-25 \mathrm{Cp}$ & $53.05(4.30)^{\mathbf{c}}$ & $83.28(3.60)^{\mathbf{b}}$ & $47.60(8.00)^{\mathbf{b}}$ \\
$95 \mathrm{~T}-5 \mathrm{Cp}$ & $28.34(7.03)^{\mathbf{b}}$ & $*$ & $*$ \\
\hline \hline
\end{tabular}


Table 6. Total fatty acid and sterol composition (\%) of Isochrysis affinis galbana (T), Chaetoceros calcitrans forma pumilum (Cp), Crassostrea gigas eggs, 2 and 19 day old larvae fed on different proportions of T and Cp in bispecific diets.

Both microalgae were sampled twice a week during the whole second set of feeding experiments while on day 19 biochemical composition was analysed of two types of larvae: incompetent $(\mathrm{NC}<320 \mu \mathrm{m})$ and competent larvae $(\mathrm{C} \geq 320 \mu \mathrm{m})$. PL corresponding to post larvae at day 26. * No data.

\begin{tabular}{|c|c|c|c|c|c|c|c|c|c|c|c|c|c|c|c|c|c|}
\hline \multirow[b]{2}{*}{ Fatty acids } & \multirow[t]{2}{*}{ Ср } & \multirow[t]{2}{*}{$\mathbf{T}$} & \multirow[t]{2}{*}{ Eggs } & \multirow[t]{2}{*}{ D2 } & \multicolumn{2}{|c|}{$\begin{array}{c}\text { 5T/95Cp } \\
\text { D19 }\end{array}$} & \multicolumn{3}{|c|}{$25 \mathrm{~T} / 75 \mathrm{Cp}$} & \multicolumn{3}{|c|}{$50 \mathrm{~T} / 50 \mathrm{Cp}$} & \multicolumn{3}{|c|}{$75 \mathrm{~T} / 25 \mathrm{Cp}$} & \multicolumn{2}{|c|}{$\begin{array}{c}\text { 95T/5Cp } \\
\text { D19 }\end{array}$} \\
\hline & & & & & NC & C & NC & C & PL & NC & C & PL & NC & C & PL & NC & C \\
\hline 14:0 & 9.07 & 22.06 & 5.71 & 4.07 & 7.58 & 7.83 & 6.80 & 8.06 & 5.17 & 5.64 & 6.95 & 4.36 & 6.46 & 7.17 & 3.44 & 5.79 & 5.30 \\
\hline 16:0 & 12.85 & 13.45 & 22.51 & 20.58 & 8.83 & 9.82 & 10.50 & 9.44 & 10.99 & 9.99 & 10.71 & 11.12 & 10.16 & 10.33 & 10.50 & 10.49 & 10.74 \\
\hline 18:0 & 0.78 & 0.85 & 3.09 & 3.58 & 1.63 & 2.23 & 1.79 & 1.78 & 2.79 & 2.09 & 1.96 & 3.00 & 1.87 & 2.14 & 2.97 & 2.34 & 2.49 \\
\hline 16:1(n-7) & 28.17 & 1.71 & 4.39 & 4.37 & 11.07 & 11.61 & 9.35 & 11.03 & 8.91 & 5.66 & 7.66 & 6.44 & 5.38 & 5.03 & 2.42 & 3.45 & 2.95 \\
\hline 20:1(n-7) & * & * & 0.94 & 1.30 & 2.93 & 2.87 & 1.45 & 2.58 & 3.33 & 2.05 & 1.53 & 3.07 & 1.08 & 1.14 & 3.45 & 1.36 & 1.46 \\
\hline $18: 2(n-6)$ & 0.41 & 3.79 & 1.43 & 1.14 & 0.89 & 0.79 & 2.26 & 2.07 & 2.43 & 3.47 & 3.66 & 4.23 & 5.89 & 6.40 & 5.96 & 7.65 & 7.56 \\
\hline $18: 3(n-6)$ & * & 0.08 & 0.17 & 0.12 & 0.16 & 0.10 & 0.27 & 0.28 & 0.16 & 0.40 & 0.42 & 0.24 & 0.71 & 0.67 & 0.35 & 0.77 & 0.74 \\
\hline 18:3(n-3) & 0.30 & 3.60 & 3.41 & 2.50 & 0.38 & 0.33 & 1.40 & 1.27 & 0.90 & 2.22 & 2.36 & 1.48 & 3.98 & 4.45 & 2.06 & 5.34 & 4.82 \\
\hline $18: 4(n-3)$ & 1.56 & 11.56 & 7.59 & 5.07 & 0.99 & 0.99 & 2.73 & 2.77 & 1.28 & 4.34 & 4.78 & 2.04 & 7.69 & 8.44 & 2.77 & 9.72 & 9.28 \\
\hline $20: 2 i$ & * & * & 0.09 & 0.15 & 0.56 & 0.55 & 0.39 & 0.28 & 0.56 & 0.37 & 0.34 & 0.54 & 0.24 & 0.25 & 0.44 & 0.20 & 0.25 \\
\hline $20: 4(n-6)$ & 0.14 & 0.09 & 1.33 & 2.04 & 1.77 & 1.24 & 1.28 & 1.19 & 1.70 & 1.54 & 1.23 & 1.73 & 1.29 & 1.25 & 2.01 & 1.31 & 1.30 \\
\hline $20: 5(n-3)$ & 26.91 & 0.38 & 14.73 & 12.15 & 21.34 & 20.74 & 17.33 & 17.24 & 14.61 & 11.26 & 12.21 & 9.75 & 6.88 & 6.91 & 6.09 & 4.41 & 4.29 \\
\hline 21:5(n-3) & * & $*$ & 1.08 & 1.07 & 0.48 & 0.52 & 0.50 & 0.40 & 0.35 & 0.51 & 0.45 & 0.40 & 0.46 & 0.44 & 0.60 & 0.50 & 0.60 \\
\hline $22: 2 i$ & * & * & 0.40 & 0.72 & 0.13 & 0.10 & 0.27 & 0.19 & 0.36 & 0.57 & 0.44 & 0.50 & 0.49 & 0.44 & 1.04 & 0.49 & 0.63 \\
\hline 22:2j & * & * & 1.93 & 3.88 & 3.67 & 3.45 & 3.46 & 2.93 & 4.39 & 4.29 & 3.23 & 3.74 & 2.40 & 2.24 & 3.64 & 2.13 & 2.54 \\
\hline 22:5(n-6) & * & 2.00 & 0.23 & 0.31 & 0.34 & 0.25 & 0.90 & 0.70 & 1.07 & 1.74 & 1.42 & 1.81 & 2.08 & 2.06 & 2.53 & 2.34 & 2.34 \\
\hline 22:5(n-3) & 0.05 & 0.23 & 1.08 & 1.18 & 0.84 & 0.79 & 0.70 & 0.50 & 0.76 & 0.55 & 0.49 & 0.59 & 0.41 & 0.40 & 0.52 & 0.45 & 0.42 \\
\hline 22:6(n-3) & 1.70 & 10.15 & 9.38 & 11.43 & 4.12 & 3.19 & 7.24 & 5.72 & 8.15 & 12.19 & 10.50 & 12.34 & 13.95 & 14.10 & 15.52 & 16.17 & 15.53 \\
\hline $\begin{array}{l}\text { 18:0dma } \\
\text { Sterols }\end{array}$ & * & * & 3.50 & 4.59 & 4.75 & 3.97 & 4.70 & 3.88 & 4.37 & 7.08 & 5.11 & 4.38 & 4.89 & 3.77 & 5.44 & 3.97 & 5.25 \\
\hline TdehydroCholesterol & * & $*$ & 7.31 & 6.44 & 0.62 & 0.37 & 0.25 & 0.25 & 0.47 & 0.24 & 0.16 & 0.41 & 0.30 & 0.22 & 0.40 & 0.43 & 0.40 \\
\hline Cholesterol & 28.23 & 7.99 & 29.51 & 28.82 & 32.61 & 36.29 & 33.39 & 34.33 & 43.60 & 28.38 & 29.48 & 40.13 & 27.95 & 18.75 & 26.32 & 13.05 & 13.21 \\
\hline Brassicasterol & * & 92.01 & 17.85 & 16.89 & 3.36 & 2.36 & 14.01 & 13.03 & 15.21 & 32.38 & 30.09 & 32.83 & 35.34 & 55.37 & 49.85 & 55.81 & 54.88 \\
\hline Desmosterol & * & * & 9.96 & 10.13 & 11.43 & 11.18 & 8.85 & 9.20 & 5.37 & 7.93 & 8.04 & 3.72 & 9.10 & 6.00 & 3.73 & 9.87 & 10.62 \\
\hline Campesterol & 1.39 & * & 1.91 & 2.06 & 3.34 & 2.09 & 1.87 & 1.76 & 2.24 & 1.46 & 1.52 & 1.78 & 1.24 & 1.10 & 1.56 & 0.12 & 2.18 \\
\hline 24MeCholesterol & 48.12 & * & 16.74 & 19.13 & 33.71 & 36.67 & 33.68 & 33.52 & 22.32 & 25.25 & 25.44 & 14.09 & 18.81 & 14.67 & 8.42 & 4.36 & 3.96 \\
\hline Isofucosterol & 17.3 & * & 8.44 & 6.51 & 5.07 & 5.8 & 4.66 & 4.81 & 3.59 & 2.55 & 3.16 & 2.22 & 2.66 & 1.56 & 1.08 & 0.78 & 0.57 \\
\hline
\end{tabular}


Fig. 1. Evolution of grazing per day per larvae of Crassostrea gigas fed on different mono- or pluri-specific diets: (a) Pavlova lutheri (P); (b) P. lutheri + Isochrysis affinis galbana (PT); (c) I. aff. galbana (T); (d) Chaetoceros calcitrans f. pumilum (Cp); (e) P. lutheri + C. calcitrans f. pumilum (PCp); (f) I. aff. galbana + C. calcitrans f. pumilum (TCp). Each condition was run in triplicate. From Day 6 to 16 this consumption was exclusively related to larvae while during metamorphosis newly settled postlarvae also contributed. Note that $y$-axis scale ranged from 0 to 10 for $a-b$ graphs while it ranged from 0 to 100 for $c, d$, $e$ and $f$ graphs. Note also that the $x$ - axis (time) corresponds to different sizes of larvae in the different treatments.
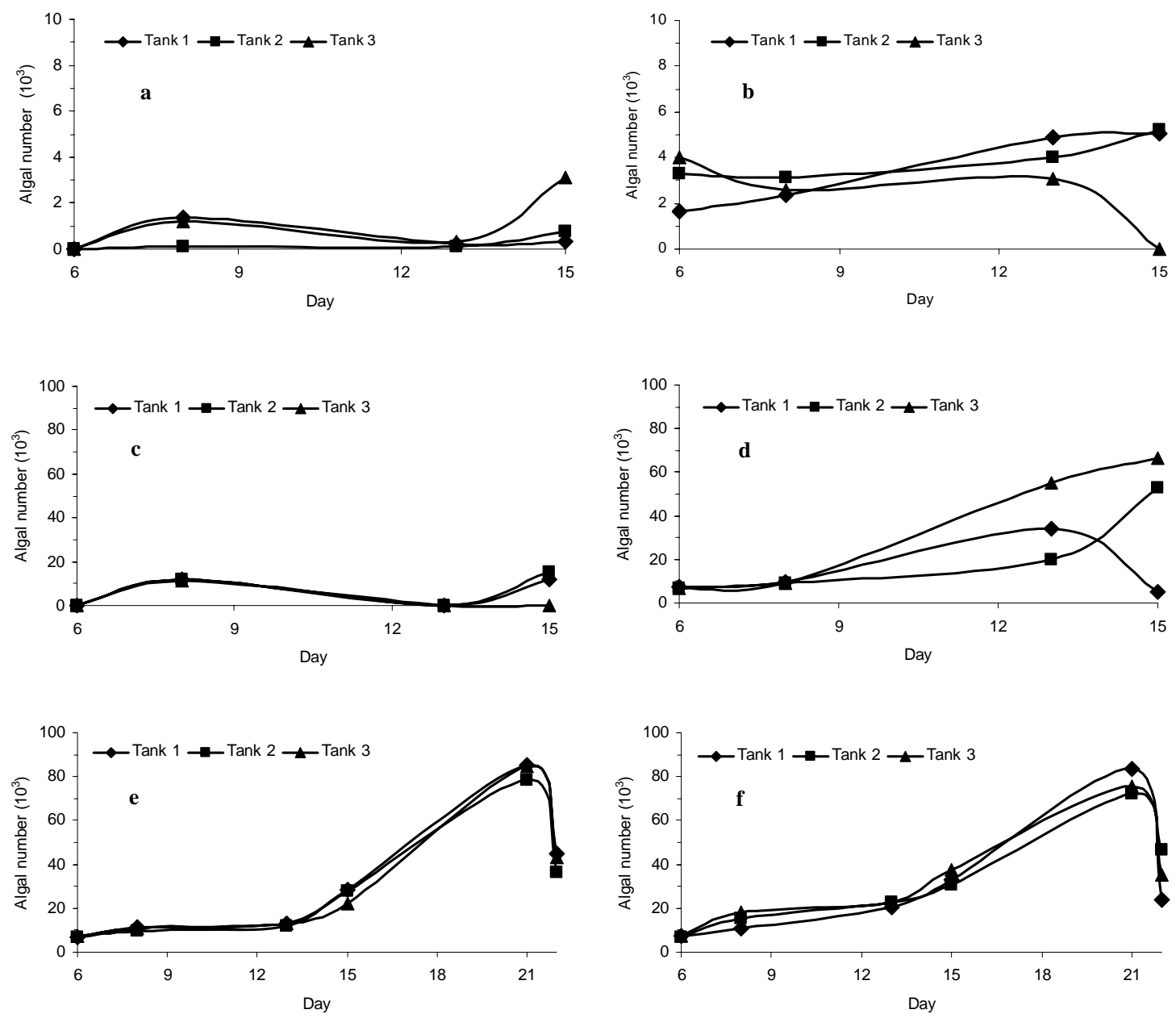
Fig. 2. Evolution from days 4 to 24 of daily grazing per larvae of Crassostrea gigas fed on different proportions of Isochrysis affinis galbana (T) and Chaetoceros calcitrans forma pumilum (Cp). Each condition was run in triplicate. From Day 4 to 19 this consumption was exclusively related to larvae while during metamorphosis newly settled postlarvae also contributed.

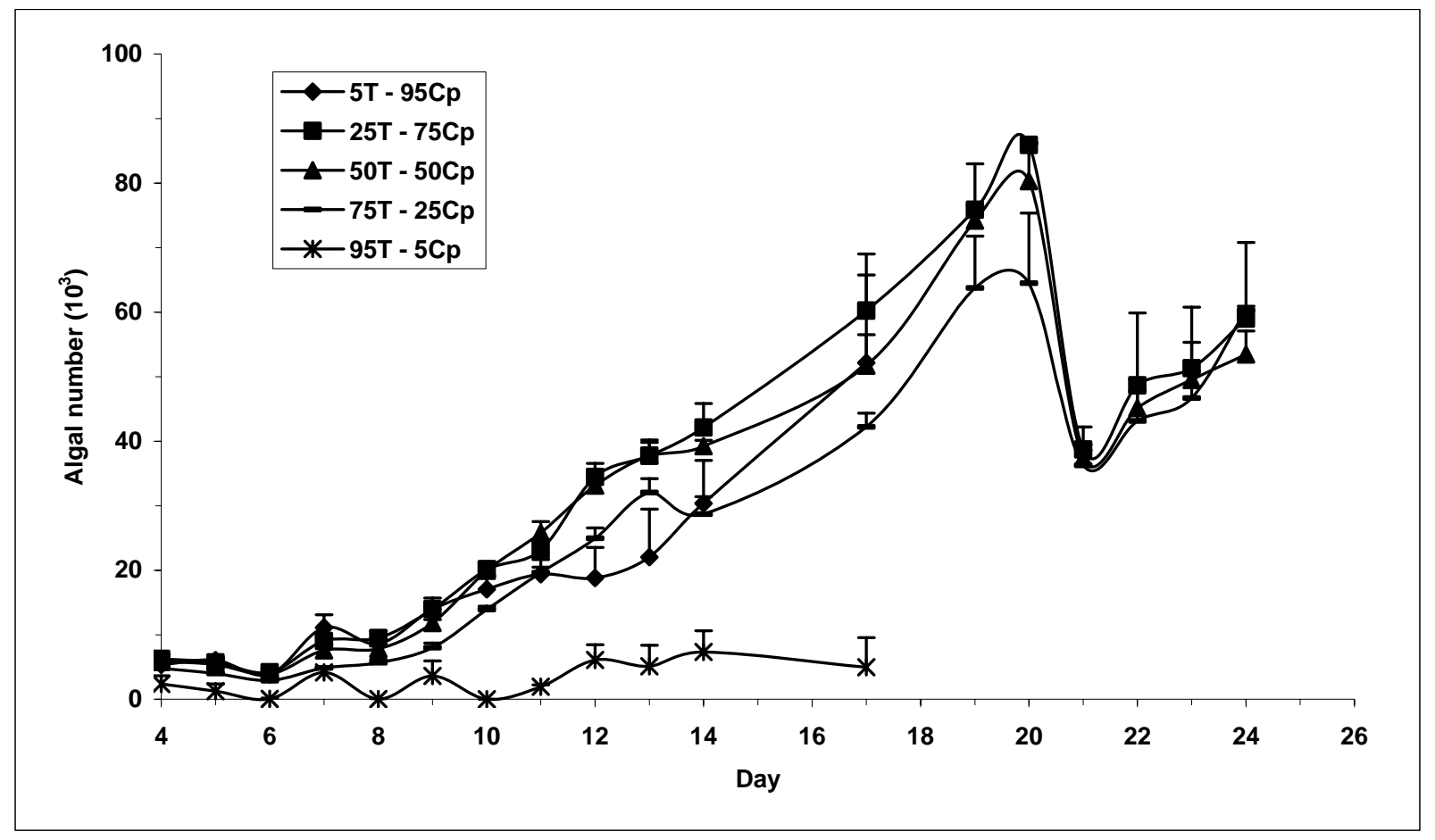


Fig. 3. Correlation circle of fatty acids and sterols in larvae (competent $=\mathrm{C}$; incompetent $=\mathrm{NC}$ ) and post larvae (PL) of Crassostrea gigas fed different proportions of Isochrysis affinis galbana (TISO or T) and Chaetoceros calcitrans forma pumilum (CHAETO): $5 \mathrm{~T}=5 \mathrm{~T} / 95 \mathrm{Cp}$; 25T = 25T/75Cp; 50T = 50T/50Cp, 75T = 75T/25Cp; 95T = 95T/5Cp.

50TNC means incompetent larvae fed 50T/50Cp; 75TPL means postlarvae fed 75T/25Cp.

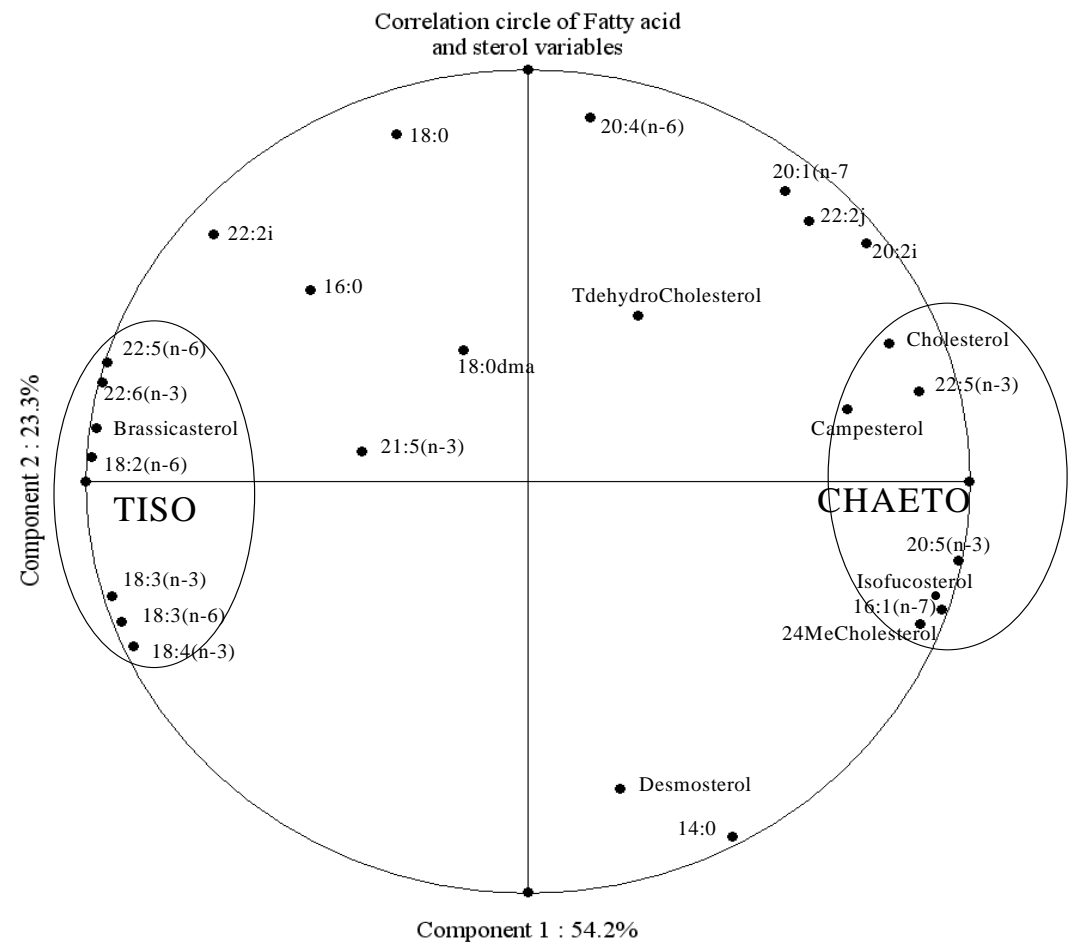

Factorial plan PC1 and PC2

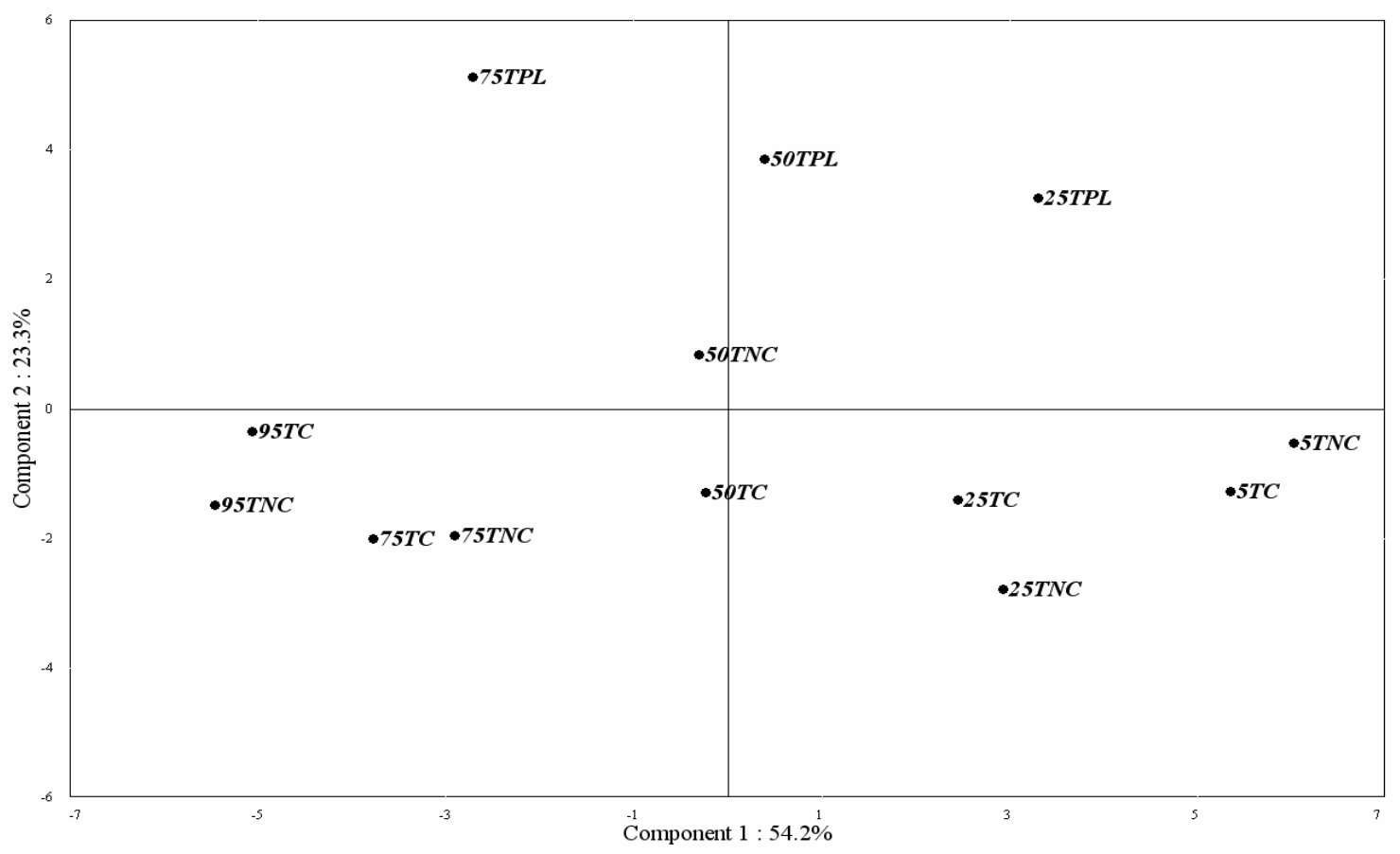

